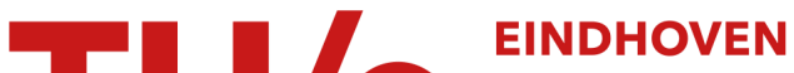 \\ UNIVERSITY OF \\ TECHNOLOGY
}

\section{Optimal cognitive distance and absorptive capacity}

\section{Citation for published version (APA):}

Nooteboom, B., Vanhaverbeke, W. P. M., Gilsing, V. A., Duysters, G. M., \& Oord, van den, A. J. (2005). Optimal cognitive distance and absorptive capacity. (ECIS working paper series; Vol. 200505). Technische Universiteit Eindhoven.

Document status and date:

Published: 01/01/2005

\section{Document Version:}

Publisher's PDF, also known as Version of Record (includes final page, issue and volume numbers)

\section{Please check the document version of this publication:}

- A submitted manuscript is the version of the article upon submission and before peer-review. There can be important differences between the submitted version and the official published version of record. People interested in the research are advised to contact the author for the final version of the publication, or visit the $\mathrm{DOI}$ to the publisher's website.

- The final author version and the galley proof are versions of the publication after peer review.

- The final published version features the final layout of the paper including the volume, issue and page numbers.

Link to publication

\section{General rights}

Copyright and moral rights for the publications made accessible in the public portal are retained by the authors and/or other copyright owners and it is a condition of accessing publications that users recognise and abide by the legal requirements associated with these rights.

- Users may download and print one copy of any publication from the public portal for the purpose of private study or research.

- You may not further distribute the material or use it for any profit-making activity or commercial gain

- You may freely distribute the URL identifying the publication in the public portal.

If the publication is distributed under the terms of Article 25fa of the Dutch Copyright Act, indicated by the "Taverne" license above, please follow below link for the End User Agreement:

www.tue.nl/taverne

Take down policy

If you believe that this document breaches copyright please contact us at:

openaccess@tue.nl

providing details and we will investigate your claim. 


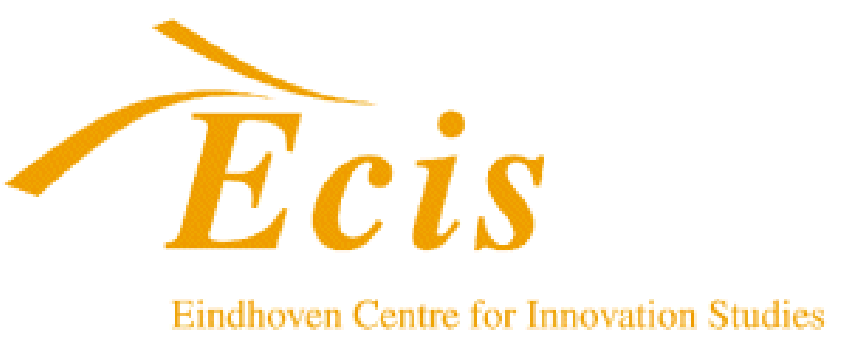

Optimal cognitive distance and absorptive capacity

B. Nooteboom, W.P.M. Vanhaverbeke, G.M. Duysters, V.A. Gilsing, A.J. van den Oord

Eindhoven Centre for Innovation Studies, The Netherlands

Working Paper 05.05

Department of Technology Management

Technische Universiteit Eindhoven, The Netherlands

April 2005 


\title{
OPTIMAL COGNITIVE DISTANCE AND ABSORPTIVE CAPACITY
}

\author{
BART NOOTEBOOM \\ Tilburg University, the Netherlands \\ WIM VANHAVERBEKE \\ Limburg University Centrum, Belgium \& \\ ECIS - Eindhoven University of Technology, the Netherlands \\ GEERT DUYSTERS \\ VICTOR GILSING \\ AD VAN DEN OORD \\ ECIS - Eindhoven University of Technology, the Netherlands
}

Corresponding author: Bart Nooteboom, e-mail: , tel: +31703478605 , mail address: Adelheidstraat 82, 2595 EE the Hague, the Netherlands

This paper tests hypotheses that in inter-firm alliances innovative performance is an inverted-U shaped function of cognitive distance, that the resulting optimal cognitive distance is higher for exploratory than for exploitative learning, and that optimal cognitive distance depends on absorptive capacity. Most hypotheses are confirmed for 994 alliances in several industries, in the period 1986-1996. The results indicate a new hypothesis that with more knowledge one needs larger cognitive distances to find novelty. 


\section{INTRODUCTION}

The number of inter-firm alliances, especially those aimed at technological learning and new knowledge creation, has grown rapidly since the mid 1980s (Hagedoorn, 1993; Duysters \& de Man, 2003). Resource interdependence and complementarities yield the most common explanation for forming such inter-organizational ties (Richardson, 1972; Pfeffer \& Nowak, 1976; Nohria \& Garcia-Pont, 1991). This is in line with the resource-based view of the firm that forms one of the most prominent theoretical perspectives in strategic management (Wernerfelt, 1984; Barney, 1991; Teece, Pisano \& Shuen, 1997; Rosenkopf \& Nerkar, 2003; Ahuja \& Katila, 2004). According to this view, which goes back to the work of Penrose (1959), firms differ in their resource positions and it is such resource heterogeneity that forms an important source of performance differences across firms. Strategic technology alliances enable firms to combine such heterogeneous resources (Porter, 1990; Prahalad \& Hamel 1990; Smith Ring \& van de Ven, 1994; Hagedoorn \& Schakenraad, 1994; Uzzi, 1997; Nooteboom, 1999; Ahuja, 2000b; Rowley et al., 2000). Particularly in high-tech sectors, alliances have become the cornerstone of innovation strategies of many companies. The majority of empirical studies have produced evidence that they positively affect corporate performance in terms of growth (Powell et al., 1996), speed of innovation (Hagedoorn, 1993) and organizational learning (Hamel, 1991; Ahuja, 2000a; Rowley et al., 2000; Hagedoorn \& Duysters, 2002).

Recently, some studies have built further on these insights, focusing on where heterogeneous resources come from, how they can be accessed, and the effectiveness of the various mechanisms that firms may employ, such as, among others, strategic technology alliances (Rosenkopf \& Nerkar, 2001; Rosenkopf \& Almeida, 2003; Ahuja \& Katila, 2004). These studies, however, tend to ignore an important question that goes beyond these issues; i.e. 'how does such resource heterogeneity, once accessed, affect the inter-firm learning 
process?', and the related question of 'what are the implications for a firm's innovation performance?' The aim of this paper is to address these particular questions. The main issue that we will address in this paper concerns the differential performance effects when resources are either very similar, or alternatively, very different. Another central issue is how this outcome is affected by a firm's R\&D capabilities (technological capital). In other words, we aim to develop an understanding of the driving factors underlying the relation between resource heterogeneity and innovative performance.

In order to deal with this question effectively, we propose to interpret resource heterogeneity in terms of the cognitive distance between the firms that hold these different resources. Here, cognition denotes a broad range of mental activity, including proprioception, perception, sense making, categorization, inference, value judgments, emotions, and feelings, which all build on each other.

From the perspective that categories of cognition are constructed from action in the world, Nooteboom $(1992,2000)$ inferred that to the extent that people have developed along different life paths and in different environments, they interpret, understand and evaluate the world differently. This leads to the notion of cognitive distance between people. Next, the question is how this notion of cognitive distance applies to firms. For organizations to achieve a common purpose, people do not have to agree on personal goals, and in the cognitive division of labor in a firm they will have dissimilar knowledge. However, they need to share certain basic perceptions and values to sufficiently align their competencies and motives. This requires a certain shared 'interpretation system' (Weick, 1979, 1995), 'system of shared meanings' (Smircich, 1983) or organizational 'focus' (Nooteboom, 2000), established by means of shared fundamental categories of perception, interpretation and evaluation inculcated by organizational culture (Schein, 1985). Differences in such organizational focus yield cognitive distance between firms. 
On the relation between cognitive distance and innovation performance, Nooteboom (1992, 1999) proposed that there is an inverted-U shaped relationship. In first instance, as cognitive distance increases, it has a positive effect on learning by interaction because it yields opportunities for novel combinations of complementary resources. However, at a certain point cognitive distance becomes so large as to preclude sufficient mutual understanding needed to utilize those opportunities. Of course, a certain mutual understanding is needed for collaboration, and familiarity certainly breeds trust (Gulati, 1995a), which facilitates successful collaboration. However, too much familiarity may take out the innovative steam from collaboration. The challenge then is to find partners at sufficient cognitive distance to tell something new, but not so distant as to preclude mutual understanding. The curve can be reconstructed as the mathematical product of a line representing absorptive capacity (Cohen \& Levinthal, 1990), which declines with cognitive distance, and a line representing the novelty value of interaction, which increases with distance, as illustrated in Figure 1.

(Insert figure 1 about here)

We are also interested in the question of how far this inverted U-shaped relationship holds across different contexts. In particular, we distinguish between a context of exploration and a context of exploitation, following March's (1991) original argument that these two categories call upon different resources and capabilities held by firms. According to the logic of our argument, we expect the positive effect of cognitive distance (novelty value) to be higher when an innovation is more radical as is the case in exploration. We expect the positive effect of cognitive distance to be low(er) in collaboration processes that are geared towards exploitation. In collaboration purely for efficient production according to existing technology, 
distance is likely to primarily yield problems. Therefore, we anticipate a differential effect of cognitive distance on innovation performance depending on the extent of exploration versus exploitation.

The article proceeds as follows. First, in a theory section we discuss the underlying theory of knowledge and learning and we formulate our hypotheses. Then, we present details about the data, the specification of variables, and the estimation method. Next, we present our main findings and a discussion of the results. All hypotheses are confirmed except the hypothesis concerning the way in which absorptive capacity (a firm's past R\&D), affects optimal cognitive distance. The contrary result yields new hypotheses, which are tested on an extended model. Finally, we provide the main conclusions and some indications for further research.

\section{THEORY AND HYPOTHESES}

In recent literature insights are converging that resource heterogeneity provides a clear potential for learning and innovation, and that strategic technology alliances can be considered as an efficient mechanism to effectuate this potential (Hagedoorn 1993, Powell e.a. 1996, Ahuja 2000a, Rowley e.a. 2000, Rosenkopf \& Almeida 2003). The theoretical framework underlying this growing understanding of the role of strategic alliances is formed by the resource-based view (RBV). The major focus in most (empirical) studies within this framework has been on comparing firms along industry and corporate characteristics. However, the majority of studies fail to adequately explain the underlying factors driving performance differences across firms (Hoopes et al., 2003). As a consequence, the basic question 'where do heterogeneous resources come from and how do they affect a firm's 
innovation performance?' has basically remained un-addressed so far. Some recent studies have started to shed some more light on these issues by focusing on the origins of heterogeneous resources, how they can be accessed, and the performance effects of the various search mechanisms employed for this purpose (Rosenkopf \& Nerkar, 2001; Rosenkopf \& Almeida, 2003; Ahuja \& Katila, 2004). In other words, these studies have focused both on the antecedents of resource heterogeneity and their consequences for a firm's innovation performance. However, in-between creating access to heterogeneous resources and their ultimate effect on innovation lies unexplored territory, in the learning process between firms that starts when resources are brought together and subsequently combined. This recombination of resources leads to new knowledge creation. In order to fill this void, we focus on the causal factors that drive this learning process. Capturing these factors may enable us to understand the differential effects on innovation performance when resources are similar or alternatively, very different. For a further development of the notion of heterogeneity we propose to use the notion of cognitive distance. There are two reasons why in our opinion the use of cognitive distance is important in understanding learning processes.

A first reason relates to the social constructivist view of knowledge that underlies the notion of cognitive distance and that we will briefly summarize. According to this view, people that have been raised in different environments or conditions interpret, understand and evaluate the world differently (Berger \& Luckman 1966, Nooteboom 1992, 2000). From a firm's perspective, this implies that a firm's development along a specific path determines its organizational focus. The upshot of this is that to the extent that firms have developed in different technological environments, they operate at a certain cognitive distance, which provides the basis for resource heterogeneity across firms. The notion of cognitive distance specifies causality and provides a stronger analytical grip and a clearer guide for empirical evaluation than the more general notion of resource heterogeneity. A second reason, as 
argued in the introduction, is that cognitive distance allows us to specify the role of absorptive capacity as decreasing, and novelty value as increasing, with increasing cognitive distance. In other words, an increase in cognitive distance creates both a problem and an opportunity. This is in contrast with various bodies of innovation literature where distance is presented as only a problem instead of also an opportunity. In a study on alliance formation in the semiconductor industry, Stuart (1998) argued that the most valuable alliances are those between firms with similar technological foci and/or operating in similar markets, whereas distant firms are inhibited from cooperating effectively. In a similar vein, the diversification literature argues that most is to be learned from alliance partners with related knowledge and skills (Tanriverdi \& Venkatraman, 2005), or from areas that firms already possess capabilities in (Penner-Hahn \& Shaver, 2005). In the literature on international business also, a pervasive view is that cognitive distance is a problem to be overcome. Johanson \& Vahlne $(1977,1990)$ employed the notion of 'psychological distance', which is seen as having an adverse effect on cross-cultural communication. When learning is discussed, in that literature, it is mostly seen as learning to cope with transnational differences, by accumulating experience in cross-border collaboration (e.g. Barkema et al., 1997), rather than taking those differences as a potential source of learning to change home country products or practices. In sum, from the viewpoint of cognitive distance, the literature has focused on its negative effects and therefore overly stressed the benefits of homogeneous resources, to the neglect of their negative effect (limited novelty value) and of the positive effect of heterogeneous resources (large novelty value). So, cognitive distance provides us with a more complete understanding of the effects of heterogeneous resources.

The focus of this article is on the role of cognitive distance in strategic alliances, with a particular focus on new technology development and innovation. In this context we abstract from most of the different dimensions of cognition. We focus on the distance between alliance 
partners in terms of technological knowledge. Following the argument outlined above, such distance, in technological knowledge, among alliance partners yields an opportunity as well as a potential problem. The argument leads to the following hypothesis:

Hypothesis 1: In alliances, innovation performance is a parabolic, inverted-U shaped function of technological cognitive distance between alliance partners

This is the core hypothesis that we want to test in this paper. In order to shed more light on this relationship we are interested in two issues. One is to test whether the expected relation between cognitive distance and innovation performance can be observed empirically. A second issue is, when such a relation can be observed empirically, to determine in how far this relation holds across different contexts. To investigate this, we make a distinction between exploration and exploitation. As we will argue, the role of cognitive distance differs profoundly between both contexts.

\section{Exploration versus exploitation}

The distinction between exploration and exploitation was discussed by March (1991). In short, exploitation is concerned with the refinement and extension of existing technologies, whereas exploration is the experimentation with new alternatives. Since exploitative and explorative learning are fundamentally different in nature, the role of cognitive distance is expected to have a different impact on the two types of learning.

Exploitation can be characterized as routinized learning, which adds to the existing knowledge base and competence set of firms without changing the basic nature of activities (Rowley et al., 2000; Hagedoorn \& Duysters, 2002). This requires a strong mutual 
understanding of the firms involved, in order to coordinate rapidly and without errors. Cognitive distance creates uncertainty and complexity, which is undesirable in such a setting. Still, some cognitive distance may be needed in order to be able to make minor adaptations. For example, in view of the need to serve different market segments or in order to regularly come up with incremental innovations in order to differentiate vis-à-vis competitors.

In contrast with exploitation, exploration can generally be characterized as a break with an existing dominant design and a shift away from existing rules, norms, routines, activities etc., to allow for Schumpeterian novel combinations. This connects with the idea that firms have to move beyond local search by reaching for novel contexts in order to overcome the limitations of contextually localized search (Stuart \& Podolny, 1996; Almeida \& Kogut, 1999; Fleming, 2001; Rosenkopf \& Nerkar, 2001, Rosenkopf \& Almeida 2003). By its nature, moving beyond local search exploration is not about efficiency of current activities. It is an uncertain process that deals with searching for new, technology based business opportunities (Nooteboom, 2000; Hagedoorn \& Duysters, 2002). This requires access to and absorption of new insights and knowledge that are, by definition, at a larger cognitive distance. Therefore, we hypothesize:

Hypothesis 2: In exploration, there is a stronger positive effect of cognitive distance on a firm's innovation performance than in exploitation.

\section{Absorptive capacity}

As argued, in the relationship between cognitive distance and innovation there are two opposing forces at work: a novelty effect that increases with larger cognitive distance and an 
absorption effect that decreases with larger cognitive distance. The novelty effect originates from making new combinations, and whether these combinations are potentially valuable is largely determined by the industry context. For the purpose of the present study, we consider this as largely exogenous, at least in the first approach. As will become clear later, the results force us to reconsider this assumption. On the other hand, we consider the absorption effect as more of an endogenous phenomenon that we need to include.

Following Cohen \& Levinthal (1990), we see absorptive capacity as determined by R\&D accumulating in technological capital (TC). Firms with large(r) amounts of TC will generally show a better performance in dealing with cognitive distance, when compared with firms with small(er) amounts of TC. To further study this, we again differentiate between exploration and exploitation. Through $\mathrm{R} \& \mathrm{D}$, firms can build up a patent portfolio, which can be seen as indicative of the codified knowledge that it has created. Moreover, R\&D enables some of the important tacit skills that are needed to absorb the (codified and tacit) knowledge generated by its partners or potential others, who operate at a certain cognitive distance. Given the characteristics of exploration, with its focus on novelty, we argue that large amounts of technological capital strengthen the ability of firms to deal with a large(r) cognitive distance. This has a positive effect on its innovation performance. By contrast, given the characteristics of exploitation, with its focus on efficiency and incremental improvements, we do not expect that absorptive capacity through formalized $\mathrm{R} \& \mathrm{D}$ is as important as in exploration. In exploitation, absorptive capacity may also be built up of more experience-based, tacit knowledge that resides within the firm and within relations with trusted, specialized suppliers and customers. Process innovations are generally not patented, for two reasons. Such process knowledge tends to be more tacit, which makes it difficult to patent as this requires some level of codification. Moreover, there is less need to patent as the tacit nature of knowledge limits the potential for spillovers and enables to maintain (some) secrecy to competitors (Malerba \& 
Breschi, 1997). Therefore, while R\&D may still play a role for absorptive capacity in exploitation, this role is different and also less visible in a patent portfolio, when compared with exploration. So, we expect a limited effect of technological capital on the ability of firms to deal with cognitive distance in exploitation.

Therefore we hypothesize:

Hypothesis 3: In exploration there is a stronger positive effect of TC on innovation performance than in exploitation.

\section{Mathematical specification}

The hypotheses can be specified more precisely in mathematical terms, as follows:

The downward sloping line for absorptive capacity (A):

$$
\mathrm{A}=\mathrm{a}_{1}-\mathrm{a}_{2} \cdot \mathrm{CD}
$$

where $\mathrm{CD}$ is the (average) cognitive distance between the focal firm and its alliance partner(s)

The upward sloping line for novelty value $(\mathrm{N})$ :

$$
\mathrm{N}=\mathrm{b}_{1}+\mathrm{b}_{2} \cdot \mathrm{CD}
$$

Multiplying (1) and (2) results in the innovative performance (L) of a company:

$$
\mathrm{L}=\mathrm{A} \cdot \mathrm{N}=\mathrm{a}_{1} \cdot \mathrm{b}_{1}+\left(\mathrm{a}_{1} \cdot \mathrm{b}_{2}-\mathrm{b}_{1} \cdot \mathrm{a}_{2}\right) \cdot \mathrm{CD}-\mathrm{a}_{2} \cdot \mathrm{b}_{2} \cdot \mathrm{CD}^{2}
$$

Equation (3) specifies the basic model to be used for an econometric test.

For exploratory collaboration we expect the positive effect of distance (the slope $b_{2}$ in equation (2)) to be larger than for exploitative collaboration. It follows from equation (3) that 
ceteris paribus, i.e. for the same values, in exploration and exploitation, of the other parameters $\left(a_{1}, a_{2}, b_{1}\right)$, for exploratory collaboration we expect a larger coefficient for both the linear and the quadratic term in distance. In collaboration only for efficient production, without any innovation, the novelty value of distance may be zero $\left(b_{2}=0\right)$, and in that case collaborative performance only declines with distance.

From (3) it follows that optimal cognitive distance (CD*) is:

$$
C D^{*}=\left(a_{1} \cdot b_{2}-b_{1} \cdot a_{2}\right) / 2 a_{2} \cdot b_{2}=1 / 2\left(a_{1} / a_{2}-b_{1} / b_{2}\right)
$$

And optimal innovative performance ( $\left.\mathrm{L}^{*}\right)$ is:

$$
\mathrm{L}^{*}=\mathrm{a}_{1} \cdot \mathrm{b}_{1}+\left(\mathrm{a}_{1} \cdot \mathrm{b}_{2}-\mathrm{b}_{1} \cdot \mathrm{a}_{2}\right)^{2} / 4 \mathrm{a}_{2} \cdot \mathrm{b}_{2}
$$

From (4) it follows that for optimal distance to be positive, we must have $b_{2}>b_{1} \cdot a_{2} / a_{1}$. From (4) and (5) it follows that for exploratory collaboration, where $b_{2}$ is larger, compared to exploitative collaboration, both optimal distance and innovative performance are larger. The proof of the latter proposition is given in Appendix A.

One simple way to specify the effect of TC on absorptive capacity, in Hypothesis 3, is to assume that higher TC yields an upward shift of the line representing absorptive capacity, i.e. a higher value of $\mathrm{a}_{1}$. Suppose that:

$$
\mathrm{a}_{1}=\mathrm{c}_{1}+\mathrm{c}_{2} \cdot \mathrm{TC}
$$

Then, from (3) we find:

$$
\mathrm{L}=\mathrm{c}_{1} \cdot \mathrm{b}_{1}+\mathrm{c}_{2} \cdot \mathrm{b}_{1} \cdot \mathrm{TC}+\left(\mathrm{c}_{1} \cdot \mathrm{b}_{2}-\mathrm{b}_{1} \cdot \mathrm{a}_{2}\right) \cdot \mathrm{CD}+\mathrm{c}_{2} \cdot \mathrm{b}_{2} \cdot \mathrm{TC} \cdot \mathrm{CD}-\mathrm{a}_{2} \cdot \mathrm{b}_{2} \cdot \mathrm{CD}^{2}
$$


In other words, according to Hypothesis 3 we then obtain a positive direct effect of TC and a positive interaction effect of TC and CD. This formula forms the basis for an empirical test of Hypothesis 3.

\section{METHODS}

\section{Data}

The hypotheses were tested on a dataset consisting of data for 116 companies in the chemicals, automotive and pharmaceutical industries. These companies were observed over a 12-year period, from 1986 until 1997. The panel is, however, unbalanced, because of new start-ups and mergers and acquisitions. Three types of data are combined in the empirical analysis. First, data about technology alliances were retrieved from the MERIT-CATI database. The 116 companies were selected to include the largest companies in these three industries that were also establishing technology based strategic alliances. Information on the establishment of alliances is hard to obtain for small or privately owned companies. Previous studies on inter-firm alliances also focused on leading companies in an industry (Ahuja, 2000a; Gulati, 1995b; Gulati \& Gargiulo, 1999). In total, 994 alliances were established in the period 1986-1996 among these companies.

Next, patent data were retrieved from the US Patent Office Database for all the companies in the sample, also those based outside the US. Working with U.S. patents - the largest patent market - is preferred over the use of several national patent systems '...to maintain consistency, reliability and comparability, as patenting systems across nations differ in the application of standards, system of granting patents, and value of protection granted' (Ahuja, 
2000a: 434). Especially in industries where companies operate on an international or global scale, U.S. patents may be a good proxy for companies' worldwide innovative performance. We only include patents that have been successfully applied for, and the corresponding year is the year a company applied for a particular patent. For companies in the three sectors the financial data came from Worldscope, COMPUSTAT and data published on the companies' websites.

\section{Measures}

The data yield a measure of cognitive distance (in technological capability), innovative output (patents), and prior cumulative patents (as a proxy for technological capital and as a determinant of absorptive capacity), and requisite control variables (such as R\&D expenditure, firm size, firm age, and year, country and industry effects). The dependent variable is measured in terms of the number of patents, with a distinction between more exploitative and more exploratory patents. Cognitive proximity (the inverse of distance) between firms is measured in terms of correlation between technological profiles derived from patent data. However, patent data are only available by firm per year, and cannot be attributed to individual alliance partners of the firm, so that the model has to be tested on the basis of average distance to the firm's alliance partners.

An overview of the main variables, with their descriptions and average values, is provided in Table 1.

Insert table 1 about here 


\section{Dependent variables.}

Yearly patent counts were used to derive the two dependent variables of exploitative and exploratory patents, as follows. For all companies technology profiles were created from the patents that a firm received in each patent class during the five years prior to a given year. A moving window of 5 years is the appropriate time frame for assessing technological impact (Podolny \& Stuart, 1995; Stuart \& Podolny, 1996; Henderson \& Cockburn, 1996; Ahuja, 2000a). Studies about R\&D depreciation (Griliches, 1979, 1984) suggest that knowledge capital depreciates sharply, losing most of its economic value within five years. The patent classes were determined at two-digit level, which resulted in approximately 400 classes. The technology profiles enable us to make a distinction between exploitative and explorative technology classes. If a company successfully files for a patent in a patent class in which it has already filed for patents during the last five years, then it is considered to be an exploitative patent. A patent is labeled as exploratory if a company successfully files for a patent in a patent class that is new for the firm, i.e. in which it did not have any patents before the last five years. Explorative patents keep this 'status' for 3 consecutive years. After that time this patent is considered to be exploitative. The three-year period is fairly arbitrary and the alternative of a five-year period was considered. Changing this time interval did not result into significant differences in the outcome of the empirical analysis

The dependent variable 'explorative patents' was then made by adding up all the patents applied for in the year of observation in the explorative patent classes. The same was done for the variable 'exploitative patents', adding up the patents in all exploitative classes.

\section{Explanatory variables.}


Cognitive distance was measured on the basis of CRTA, which is Pearson correlation index of the distribution across technological classes of the revealed technological advantages (RTA) of each firm relative to the other sample firms. The RTA of a firm in a particular technological field is given by the firm's share in that field of the US patents granted to all companies in the study, relative to its overall share of all US patents granted to these companies. The RTA index varies around one, such that a value greater than one suggests that a firm is comparatively specialized in the technology in question, given its overall innovative performance. Positive values of CRTA indicate similarity of the pattern of relative technological specialization of firms, as it appears from the distribution of their patent activity across technological fields. For each firm and each year, a profile was constructed of its revealed technological advantage (RTA) in each patent class. A company's RTA-index in a patent class is defined as the firm's share of patents in that class (compared to all its alliance partners) divided by its share in all patent classes. The correlation coefficient was computed pairwise between the RTA-profile of the focal firm and that of each of its alliance partners. The CRTA variable is then calculated as the average of these correlations. The values for CRTA can theoretically vary from -1 to 1 . As positive (negative) values indicate smaller (larger) cognitive distances, we choose to transform this variable into a new one (CD or 'cognitive distance') with a minimum value of zero and a maximum of one, where higher values indicate larger cognitive distance.

Cumulative technological capital is calculated as the number of patents that a firm obtained in the previous five years (as used in the calculation of the technology profiles, see above). Patents granted to a company are used to measure, in an indirect way, the technological competence of a company (Narin et al., 1987). 


\section{Control variables}

In order to avoid bias from other effects on performance, control variables are included in the analyses. First, firm size is also expected to have an effect. We include the natural logarithm of 'corporate sales', a proxy for firm size, as a control variable. Firm size is expected to enhance exploitative learning (Acs \& Audretsch, 1991). Large firms have the financial means and vast technological and other resources to invest heavily in R\&D. Assuming there exists a positive correlation between technological input and output (Pakes \& Griliches, 1984), large firms then tend to have a higher rate of innovation than small firms. However, Nooteboom (1991) hypothesized, and Nooteboom \& Vossen (1995) empirically confirmed that while in most industries large firms participate more in $R \& D$ than small firms, when small firms participate they do so more intensively and efficiently. Ahuja \& Lampert (2001) also found that increasing firm size results in decreasing innovation performance. Also, larger firms usually experience problems in diversifying into new technological areas inhibiting experimentation and favoring specialization along existing technological trajectories (Levinthal \& March, 1993; Ahuja \& Lampert, 2001). As a result, we expect that large firms have an advantage over small ones in exploiting technological dynamics with a cumulative nature, but they may be at a disadvantage with respect to experimenting and exploring new technological fields.

Second, as documented extensively in the innovation literature, $R \& D$ expenditure is expected to have an effect on patents (Ahuja \& Katila, 2001; Hagedoorn \& Cloodt, 2003). Therefore, the natural logarithm of $\mathrm{R} \& \mathrm{D}$ expenditures is an interesting control variable but it is highly correlated with firm size. In order to separate R\&D effects from size effects we chose to include R\&D-intensity to take into account the variance in inputs for innovation activity (Hall \& Ziedonis, 2001). We expect a positive and significant coefficient in the 
regressions.

Third, firm age may have an effect too. Generally, one would expect older firms, with their accumulated experience, to be better at exploitation, and younger firms, with lower stakes and habituation in old technologies, to be better at exploration.

Finally, there may be unknown effects of specific years, for which use will be made of year dummy variables, and there may be regional effects, which we control by means of dummy variables for the EU and the US. Industry specific effects are also captured by two extra dummy variables. The propensity to patent may be partly determined by the nationality and/or the sector of the companies. Annual dummy variables may capture the ever-growing importance of intellectual capital, forcing companies to file more patents over the years, or macroeconomic conditions that may affect the three industries.

In sum, control variables are R\&D intensity, firm size, firm age, and industry, regional and time effects.

\section{Estimation}

The dependent variable is a count variable and takes only nonnegative integer values - i.e. the number of patents a firm filed for in a particular year. A Poisson regression approach provides a natural baseline model for such data (Hausman et al., 1984; Henderson \& Cockburn, 1996).

The basic Poisson model for event count data can be written as follows:

$$
f\left(y_{i j t} \mid \lambda_{i j t}\right)=\frac{\exp \left(-\lambda_{i j t}\right) \lambda_{i j t}^{y_{i j t}}}{y_{i j t} !}
$$

where the parameter $\lambda_{\mathrm{ijt}}$ represents the mean and the variance of the event count and $\mathrm{y}_{\mathrm{ijt}}$ the 
observed count variable.

It is furthermore assumed that:

$$
\ln \left(\lambda_{\mathrm{ijt}}\right)=\beta \mathrm{X}_{\mathrm{ijt}}
$$

with $\mathrm{X}_{\mathrm{ijt}}$ being a vector of independent variables and $\beta$ a parameter vector.

The above specification in equation (8) assumes that the mean and variance of the event count are equal. However, for pooled cross-section count data this assumption is likely to be violated, since it is well know that count data suffer from overdispersion (i.e. the variance exceeds the mean). This overdispersion is particularly relevant in the case of unobserved heterogeneity, i.e. the possibility that identical firms on the measured characteristics are still different on unmeasured characteristics. Since we use pooled cross-section data with several observations on the same firms at different points in time, we modeled the data using a random effects Poisson estimator: it does not assume within-firm observational independence for the purpose of computing standard errors.

Unobserved heterogeneity may be the result of differences between companies in their innovation generating capabilities, and as a consequence, also in their propensity or ability to patent. Such unobserved heterogeneity, if present and not controlled for, can lead to overdispersion in the data or serial correlation. Therefore, in line with Hausman et al. (1984) we use a panel Poisson approach by introducing an individual unobserved effect in the conditional mean of the Poisson distribution. In particular, a gamma distribution with parameters $\theta_{\mathrm{ijt}}$ and $1 / \alpha$ is assumed for the conditional mean, where $\ln \left(\theta_{\mathrm{ijt}}\right)=\alpha \mathrm{X}_{\mathrm{ijt}}$ This changes the resulting distribution of the dependent variable into a panel negative binomial the density of which equals: 


$$
f\left(y_{i j t} \mid \theta_{\mathrm{ijt}}, \alpha\right)=\frac{\Gamma\left(\theta_{i j t}+y_{i j t}\right)}{\Gamma\left(y_{i j t}+1\right) \Gamma\left(\theta_{i j t}\right)} \cdot\left(\frac{\alpha}{1+\alpha}\right)^{y_{i j t}}\left(\frac{1}{1+\alpha}\right)^{\theta_{i j t}}
$$

where $\Gamma($.$) is a standard gamma distribution and \alpha>0$.

The negative binomial model has the advantage over the standard model that the former allows for a different mean and variance. More specifically, the ratio of the variance to the mean can be calculated from equation (10) as $1+\alpha$, and is permitted to grow with the mean (Hausman et al., 1984). The parameter $\alpha$, which is the reciprocal of the standard deviation of the heterogeneity distribution, is calculated from the observed data and captures overdispersion.

\section{RESULTS}

As a base case to compare our results against, we first present the outcome with only the control variables. Model 1 in Table 3 represents the impact of the control variables both on exploitative patents and explorative patents.

Insert Table 3 about here

In Model 2, we present the results for the basic explanatory model, according to equation (3), which in addition to the control variables includes the linear and quadratic terms in cognitive distance. Model 3 adds technological capability as an additional explanatory 
variable as was suggested in Hypothesis 3, as specified in equation (7). Technological capital - or the existing patent portfolio - of a firm is supposed to improve its absorptive capacity improving the innovative (exploitative and explorative) performance for varying distances in cognition. As specified in equation (7), this is expected to yield a positive effect of TC as well a positive effect of the interaction between TC and CD.

First, we have a look at the results of Model 2 for both exploitative and explorative learning. These results confirm the basic hypothesis (Hypothesis 1) that innovation performance is a parabolic, inverted-U shaped function of cognitive distance between alliance partners in the case of explorative patents: the linear term of cognitive distance has a (strongly significant) positive effect and the quadratic term a (strongly significant) negative effect. We didn't find an inverted-U shaped function for exploitative patents. There is a linear negative relationship between cognitive distance and innovative performance in terms of "exploitative patents"- the coefficient of the quadratic term is not significantly different from zero. As a result, firms that further exploit existing technological competencies are more innovative when they stick to the patent classes in which they are already active or to those that are strongly related to it. While increasing cognitive distance has a negative effect on the innovative performance in the case of exploitative patents, it has a positive effect on explorative learning. The results of Model 2 show that for exploratory patents optimal cognitive distance is 38.1 on a scale between zero and hundred. At that optimum, innovative performance is $162 \%$ higher compared to the baseline case were CD equals zero. Hence, Hypothesis 2 is corroborated.

Model 3 tests equation (7) where absorptive capacity is not only a function of cognitive distance but also of the technological capital (TC) of an innovating firm, as has been specified in equation (6). Concerning the effects of technological capital in exploration and in exploitation (Hypotheses 3), we find a positive and significant effect for technological capital 
(prior cumulative patents) and a negative impact of technological capital in interaction with cognitive distance (CD*TC). The introduction of these two variables also mitigates the (negative) effect of cognitive distance on innovativeness in the case of exploitative patents.

All results are in line with our hypotheses, except the last one: we hypothesized that the interaction term of TC and CD would have a positive effect, but we find a significant negative effect. This is the case for both exploitative learning and explorative learning. In both cases, the existing technological capital of a firm becomes a burden at (high) cognitive distance levels: For both exploitation and exploration the effect of technological capital on innovative performance remains positive although the impact of technological capital is tempered with increasing cognitive distance. In the case of explorative patents technological capital could even have a negative impact on the innovative performance at higher technological distances if $\mathrm{CD}$ is larger than $54.3(=0.8005 / 0.014815)$. The maximal cognitive distance for our sample of firms is 52.5 (see Table 2), and thus, TC always has a positive effect on explorative learning for our sample of firms ${ }^{1}$. In sum, technological capital has a positive effect on both exploitative and explorative learning and the impact on the latter is much larger, as we expected in hypothesis 3 . This positive effect is gradually tempered at larger cognitive distances. In the case of explorative learning, technological capital may even become a liability at very high levels of cognitive distance.

Most control variables have the expected effect on the exploitative and explorative learning. Size has a positive and significant effect on the rate of innovation both for exploiting current technologies as well as for exploring new technological areas. Since this explanatory variable is in the log form, its coefficient in the Poisson specification can be interpreted as elasticitie between firm size and the dependent variables. The coefficients are in both tables smaller than one suggesting - all else equal - that the frequency of patenting increases with 
firm size but less than proportionately. As a result, small firms are more technology intensive than their larger counterparts. Interestingly, the coefficient for 'firm size' in the exploitation of current technologies is significantly larger than in the case of the exploration new technologies. This difference shows that that the small firms have a disproportionately large share of explorative patents. This is in line with the results of previous research that show that new and more radical inventions are likely to originate with entrants rather than incumbents (Cooper \& Schendel, 1976; Foster, 1986).

As expected, R\&D-intensity has a positive and significant effect on the innovation rate of the companies in the sample, and its impact is significantly larger in the case of exploitative learning compared to explorative learning. This strong impact on exploitative patents indicates that an increase in R\&D-efforts will lead to more patents in the patent classes that the firm already masters. This is less the case for exploration of new technologies reflecting the high levels of uncertainty in explorative research.

As expected, age of the firm has a positive effect on exploitative patents, but a negative, though not significant, effect on exploratory patents. This result suggests that established companies that had time to develop capabilities in particular technological fields have a clear competitive advantage over new entrants that still have to develop this technological expertise. By contrast, the negative coefficient for 'explorative patents' indicates that newly established firms might have a slight advantage in exploring new technological fields and (although we have no conclusive evidence). This is in line with previous research that focused on the role of new firms in the creation of new technologies (Methe et al., 1997).

To check for inter-industry differences in the propensity to patent (both explorative and exploitative) we introduced two dummy variables - car manufacturer and chemical industry, while the pharmaceutical industry is the default - to control for these differences. The positive in the case of explorative learning. In the case of exploitative learning the impact is rapidly 
coefficients in both tables are negative and statistically significant, suggesting that pharmaceutical companies are more inclined to patent in both existing and new patent classes than firms in the two other industries. By contrast, dummy variables indicating in which economic block the companies are based (America, Europe and the Middle-East, or the Far East) have no significant coefficients. Most year dummy variables have significant effects (not reported in the tables) indicating that the propensity to patent - both in existing and new patent classes - is variable over time.

Finally, overdispersion is a feature of our data: The estimates of the overdispersion parameter $(\alpha)$ reported in the last row show that the hypothesis of no overdispersion is clearly rejected.

\section{DISCUSSION}

The erosion of the positive effect of technological capital on explorative learning and the possibility of a negative effect is at odds with Hypothesis 3, where we argued that larger technological capital generally shows a better performance in dealing with cognitive distance. More specifically, we hypothesized that higher TC yields a general increase of absorptive capacity, in the form of an upward shift of the line that represents such capacity (see Figure 1). However, according to the mathematical analysis that would yield a positive effect of the interaction term of TC and cognitive distance: see equation (7), but we observe a significant negative effect. Further inspection of the mathematics, elaborated in Appendix B, indicates that there are three possible explanations for the observed negative effect of the interaction variable TC.CD, as follows:

declining below zero as CD is increasing. 
1. Technological capital not only increases the intercept of the line for absorptive capacity, but also its (negative) slope. This would imply that a broader scope of technological capability becomes a liability for absorption at large cognitive distance. A wider field of competence makes it more difficult to understand something that is radically different. Along these lines, several authors (Ahuja and Lampert, 2001; Helfat, 1994; Martin \& Mitchell, 1998; Nelson \& Winter, 1982; Stuart \& Podolny, 1996) have argued that these organizations have a propensity to adopt solutions in the neighborhood of existing solutions. Organizational routines and bureaucratic convenience favor projects that look for new solutions near old solutions over projects that rely on completely new principles. Resource allocation also follows established norms, controls, and procedures so that projects that build on antecedents are likely to be more easily selected and financed. This is rational when there is a complex system of many tightly coupled elements, because then the incorporation of a novel element may upset the systemic integrity of the system as a whole (Nooteboom 2000). Mathematical elaboration, given in appendix B, shows that this would yield a second interaction term, of technological capital and the square of cognitive distance $\left(\mathrm{TC} . \mathrm{CD}^{2}\right)$, with a negative effect.

2. Technological capital (also) yields an upward shift of the line representing the novelty value of cognitive distance. This reflects the idea that a broad technological basis yields better opportunities for Schumpeterian novel combinations: whatever a partner has to offer has a larger chance of yielding a connection with something within the scope of technological capability. Appendix B shows that this yields no effect of the interaction term TC.CD 2 .

3. Technological capital (also) yields a smaller slope of the line of novelty value as a function of cognitive distance. This implies a principle of decreasing returns to knowledge: with a broader technological basis one requires a larger distance to generate novelty value. In other words, this may be called the 'boredom hypothesis': the more one already knows, the further afield one has to go, in more exotic relations, to still find something new. Appendix B 
shows that this yields a positive effect of the interaction term TC.CD ${ }^{2}$

We can now discriminate between these three alternative explanations on the basis of the significance and the sign of an effect of the new interaction term TC.CD ${ }^{2}$. The results of the corresponding test are given in Model 4 of Table 3 and are illustrated in figures 2,3 and 4. The coefficient of the variable TC.CD ${ }^{2}$ is in both cases positive and significantly different from zero. These results support the $3^{\text {rd }}$ explanation: the idea that technological capital might reduce the steepness of the line of novelty value as a function of cognitive distance. Larger cognitive distance adds proportionately less value for the firm, the larger its existing technological competencies. In addition, the coefficient of the explorative patents is significantly larger than for the exploitative patents (Table 3). This indicates that the tempering effect of the existing technological competence in companies is more drastic in the exploration of new fields than in the exploitation of technological fields where the innovating company has already build its strength.

(Insert Figures 2, 3 and 4 about here)

However, as shown in appendix $\mathrm{B}$, if higher $\mathrm{TC}$ only reduces the slope of the line for novelty value, there would be no direct effect of TC on innovative performance, but we do observe that effect. To yield that empirical result, TC must also either increase the intercept of the line for absorptive capacity, as originally hypothesized, or also increase the intercept of the line for novelty value, or both.

\section{CONCLUSIONS}




\section{Key findings and implications}

In this paper we have considered the relation between cognitive distance and innovation performance of firms cooperating in technology-based alliances. We have interpreted cognitive distance in terms of differences in technological knowledge between firms. The key finding is that the hypothesis of an inverted U-shaped effect of cognitive distance on innovation performance of firms is confirmed. Moreover, as expected, we found that the positive effect for firms is much higher when engaging in more radical, exploratory alliances than in more exploitative alliances.

The effect of cumulative $R \& D$, expressed in the scope of patents, turns out to be mixed. It may increase absorptive capacity, as originally hypothesized, and it may also increase the level of novelty value (intercept of the line), but there is clear evidence that it also reduces the effect of cognitive distance on novelty value (slope of the line of novelty value).

The implications are important, for theory and practice. In both theory and practice, rather than assuming that differences in cognition (in terms of technological knowledge) only complicate collaboration one should also recognize the positive potential of such differences.

A consequence for firms is that they need to be aware that in cooperating with others in alliances there is a trade-off to be made between the opportunity of novelty value and the risk of misunderstanding. This is an important insight that complements findings reported in some recent studies. In this recent literature the benefits of searching for and accessing heterogeneous resources have been stressed considerably (Ahuja \&Katila, 2004; Rosenkopf \& Nerkar, 2001; Rosenkopf \&Almeida, 2003), apparently driven by the (implicit) goal to benefit from a rise in novelty value when cognitive distance increases. However, this clearly ignores the notion that employing such strategies comes at a risk of decreasing understanding with a negative effect on innovation performance. Whereas in the literature on international business, 
indicated earlier, the positive effect of distance is neglected, this literature runs the risk of neglecting its problems. To deal with this, firms should seek partners that are at an optimal cognitive distance. They may assess this in ways similar to those employed here: by inspecting their patent portfolio.

Such optimal distance is not fixed, but depends on one's past investment in building technological knowledge as a basis of absorptive capacity. The mixed effect of cumulative R\&D suggests that while it may improve the general ability to understand and appreciate novelty value in collaboration, there are decreasing returns to novelty: the more one knows the further away one has to look for novelty.

Additional findings were that, as expected from earlier studies of innovation and firm size, large firm advantage is less in more radical, exploratory innovation than in more exploitative innovation. Also, as expected, older firms perform better in more exploitative alliances but not, and perhaps worse, in exploratory alliances. Finally, in the absence of any remaining effects from different regions (US, EU), it appears that any regional differences are captured in the explanatory variables.

\section{Limitations and future directions}

One limitation of the present study is that by taking firms as the unit of analysis, we had to average cognitive distance across the various alliance partners of the firm. An alternative is to take alliances as the unit of analysis, with their individual results in terms of innovation.

The present study does not include a test of the derived hypothesis that ongoing duration of an alliance reduces cognitive distance, yielding an inverted-U shaped effect of duration on innovative performance, which was confirmed by Wuyts et. al. (2005). In the data used here, no reliable measure of alliance duration could be constructed. 
The dichotomization of explorative and exploitative patents in two categories could be removed by introducing an interval variable representing the degree of exploration in the new patents of a company in a particular year. The information entailed in this type of variable is richer than the two categories we used now.

It would be interesting to further test the indication found in this study that experience in $R \& D$ reduces the marginal novelty from cognitive distance, and to try and answer the question, left open by our empirical results, whether such experience increases both the level of absorptive capacity and the novelty value, or only one of them.

Next, in this paper we only elaborated on the cognitive distance between the focal firm and its alliance partners, not on the cognitive distance among the alliance partners themselves. An interesting direction for future research is to analyze how the average cognitive distance between the alliance partners might affect the impact of alliance portfolio's on the innovativeness of companies, both in terms of exploitation and exploration.

A more fundamental challenge is the following. In the underlying theory of knowledge, cognition is assumed to be a broad concept, including both cognition in the narrow sense of intellect, in perception and inference, and cognition in the wider sense of reflexive, normative and emotional behavior, in perception, attribution, and value judgments. In the present study we considered only cognitive distance in a limited sense of differences in technological knowledge, inferred from patent data. In future research it would be worthwhile to separate out differences in different dimensions of cognition. The hypothesis for such a study would be that for optimal collaboration distance should be relatively small in cognition concerning governance, i.e. in ways and styles of dealing with relational risk, in more or less inclination to trust, for example, and should be relatively large in substantive aspects of intellectual knowledge. Wuyts et. al. (2005) give an example of a study where a distinction was made between difference in technological competence and distance in organizational variables. 


\section{Appendix A: Effect of the slope of the line for novelty value $\left(b_{2}\right)$}

For the effect of $b_{2}$ on optimal cognitive distance $\left(C D^{*}\right)$ and corresponding innovative performance $\left(\mathrm{L}^{*}\right)$ we consider their derivatives with respect to $b_{2}$ :

$\mathrm{d} \mathrm{CD} * / \mathrm{d} \mathrm{b}_{2}=1 / 2 \mathrm{~b}_{1} / \mathrm{b}_{2}^{2}>0$

This proves that an increase of $b_{2}$ yields an increase of optimal cognitive distance.

$d L^{*} / d b_{2}=\left(a_{1} b_{2}-b_{1} a_{2}\right)\left(a_{1} b_{2}+b_{1} a_{2}\right) / 4 a_{2} b_{2}^{2}>0$

if $a_{1}>b_{1} a_{2} / b_{2}$, and this was assumed earlier.

This proves that an increase of $b_{2}$ yields an increase of optimal innovative performance.

\section{Appendix B: Negative effect of interaction TC.CD}

Alternative 1

Higher TC increases the negative slope of the line for absorptive capacity $\left(a_{2}\right)$

Let $a_{2}=d_{1}+d_{2} \cdot$ TC

Substitution into the formula (3) for innovative performance L then yields:

$L=a_{1} b_{1}+\left(a_{1} b_{2}-b_{1} d_{1}\right) C D-b_{1} d_{2} \cdot T C \cdot C D-b_{2} d_{1} \cdot C D^{2}-b_{2} d_{2} \cdot T C \cdot C D^{2}$ 
Here there is a negative effect of the interaction variable TC.CD and a negative effect of the interaction variable TC.CD ${ }^{2}$ Note that there is no effect of TC separately.

\section{Alternative 2}

Higher TC increases the intercept of the line for novelty value $\left(b_{1}\right)$

Let $b_{1}=e_{1}+e_{2} \cdot T C$

Substitution into (3) yields:

$L=a_{1} e_{1}+a_{1} e_{2} \cdot T C+\left(a_{1} b_{2}-a_{2} e_{1}\right) C D-a_{2} e_{2} \cdot T C \cdot C D-a_{2} b_{2} \cdot C D^{2}$

Here there is also a negative effect of interaction TC.CD, no effect of interaction TC.CD ${ }^{2}$, and there is a positive effect of TC directly.

\section{Alternative 3}

Higher TC decreases the positive slope of the line for novelty value $\left(b_{2}\right)$

Let $b_{2}=f_{1}-f_{2} . T C$

Substitution into (3) yields:

$L=a_{1} b_{1}+\left(a_{1} f_{1}-b_{1} a_{2}\right) \cdot C D-a_{1} f_{2} \cdot T C \cdot C D-a_{2} f_{1} \cdot C D^{2}+a_{2} f_{2} \cdot T C \cdot C D^{2}$

Here there is also a negative effect of the interaction TC.CD, a positive effect of interaction TC.CD ${ }^{2}$, and no direct effect of TC. 
For a positive effect of TC on the intercept of the line for absorptive capacity $\left(\mathrm{a}_{1}\right)$, assuming $\mathrm{a}_{1}=\mathrm{c}_{1}+\mathrm{c}_{2} . \mathrm{TC}$, we found, in (7),

$\mathrm{L}=\mathrm{c}_{1} \cdot \mathrm{b}_{1}+\mathrm{c}_{2} \cdot \mathrm{b}_{1} \cdot \mathrm{TC}+\left(\mathrm{c}_{1} \cdot \mathrm{b}_{2}-\mathrm{b}_{1} \cdot \mathrm{a}_{2}\right) \cdot \mathrm{CD}+\mathrm{c}_{2} \cdot \mathrm{b}_{2} \cdot \mathrm{TC} \cdot \mathrm{CD}-\mathrm{a}_{2} \cdot \mathrm{b}_{2} \cdot \mathrm{CD}^{2}$

To reproduce the empirical results of a positive direct effect of $\mathrm{TC}$, a positive effect of $\mathrm{CD}$, a negative effect of $\mathrm{CD}^{2}$, a negative effect of interaction TC.CD, and a positive effect of interaction TC.CD ${ }^{2}$, we need a combination of (B3) and (B2) and/or (B4). In other words, TC has a negative effect on the positive slope of the line for novelty value, and a positive effect on either the intercept of the line for absorptive capacity or the intercept of the line for novelty value, or both. 


\section{REFERENCES}

Acs, Z. \& Audretsch, D.B. 1991. Innovation in large small firms: An empirical analysis. American economic Review, 78: 678-690.

Ahuja, G. 2000a. Collaboration networks, structural holes, and innovation: A longitudinal study. Administrative Science Quarterly, 45: 425-455.

Ahuja, G. 2000b. The duality of collaboration: inducements and opportunities in the formation of interfirm linkages, Strategic Management Journal, 21(3): 317-343.

Ahuja, G. \& Lampert, C.M. 2001. Entrepreneurship in the large corporation: A longitudinal study of how established firms create breakthrough inventions. Strategic Management Journal, 22: 521-543.

Ahuja, G., \& Katila, R. 2001. Technological acquisitions and the innovation performance of acquiring firms: A longitudinal perspective. Strategic Management Journal, 22(3): 197220.

Ahuja, G., \& Katila, R. 2004. Where do resources come from? The role of idiosyncratic situations. Strategic Management Journal, 25(8-9): 887-907.

Almeida, P. \& Kogut. B. 1999 . Localization of knowledge and the mobility of engineers in regional networks. Management Science, 45(7 ): 905 -917.

Argyris, C. \& Schön, D. (1978). Organizational learning, Reading, MA.: Addison - Wesley.

Barkema, H.G., Shenkar, O., Vermeulen, F. \& Bell, J.H.J.. 1997. Working abroad, working with others: How firms learn to operate international joint ventures, Academy of Management Journal, 40: 426-442.

Barney, J. B. 1991. Firm resources and sustained competitive advantage. Journal of Management, 17(1): 99-120.

Berger, P. \& Luckmann, T. 1966. The social construction of reality. New York: Anchor. 
Cohen, M. D. \& Levinthal, D. A. 1990. Absorptive capacity: A new perspective on learning and innovation. Administrative Science Quarterly, 35: 128 - 52.

Cooper A, \& Schendel D. 1976. Strategic responses to technological threats. Business Horizons 19(1): 61-69.

Duysters, G. \& de Man, A. 2003. Transitory alliances: An instrument for surviving turbulent industries. $R \&$ D Management, 33(1): 49-58.

Fleming, L. 2001. Recombinant uncertainty in technological search. Management Science 47(1): 117-132.

Foster R. 1986. Innovation: The Attackers Advantage. New York: Summit Books.

Griliches, Z. 1979. Issues in assessing the contribution of research and development to productivity growth. Bell Journal of Economics, 10: 92-116.

Griliches, Z. 1984. Patents and productivity, Chicago, IL: NBER..

Gulati, R. 1995a. Does familiarity breed trust? The implications of repeated ties for contractual choice in alliances. Academy of Management Journal, 30(1): 85-112.

Gulati, R. 1995b. Social structure and alliance formation patterns: A longitudinal analysis.

Administrative Science Quarterly, 40(4): 619-652.

Gulati, R \& Garguilo, M. 1999. Where do interorganizational networks come from? American Journal of Sociology, 104(5): 1439-93.

Hagedoorn, J. 1993. Understanding the rationale of strategic technology partnering: Interorganizational modes of cooperation and sectoral differences. Strategic Management Journal, 14: 371-385.

Hagedoorn, J. \& Schakenraad, J. 1994. The effect of strategic technology alliances on company performance. Strategic Management Journal, 15: 291-309. 
Hagedoorn, J. \& Cloodt, M. 2003. Measuring innovative performance: is there an advantage in using multiple indicators? Research Policy 32: 1365-1379.

Hagedoorn, J. \& Duysters, G. 2002. Learning in dynamic inter-firm networks - The eff icacy of quasi-redundant contacts, Organization Studies, 23(4): 525-548.

Hall, B.H. \& Ziedonis, R.H., 2001. The patent paradox revisited: an empirical study of patenting in the US semiconductor industry. 1979-1995. Rand Journal of Economics, 32(1): 101-128.

Hamel, G. 1991. Competition for competence and inter-partner learning within international strategic alliance. Strategic Management Journal, 12, Special issue: 83-103.

Hausman J., Hall B. \& Griliches, Z. 1984. Econometric models for count data with an application to the patents-R\&D relationship. Econometrica, 52: 909-938.

Helfat C.E. 1994. Evolutionary trajectories in petroleum firm R\&D. Management Science, 40: $1720-1747$.

Henderson, R. \& Cockburn, I. 1996. Scale, scope and spillovers: the determinants of research productivity in drug discovery. Rand Journal of Economics, 27(1): 32-59.

Hoopes, D.G., T.L. Madsen and G. Walker. 2003. Guest editor's introduction to the special issue: why is there a resource-based view? Toward a theory of competitive heterogeneity. Strategic Management Journal, 24: 889-902

Johanson, J. \& J. Vahlne 1977. The internationalization process of the firm - a model of knowledge development and increasing foreign market commitment. Journal of International Business Studies, spring/summer: 23-32.

Johanson, J. \& J. Vahlne 1990. The mechanism of internationalization. International Marketing Review, 7(4): 11-24. 
Levinthal, D.A. \& March, J.G. 1993. The myopia of learning. Strategic Management Journal, Winter Special Issue, 14: 95-112.

Malerba, F. \& Breschi, S. 1997. Sectoral innovation systems: technological regimes, Schumpetarian dynamics and spatial boundaries, in: C. Edquist (ed.), Systems of innovation, technologies, institutions and organizations, London, Pinter.

March, J. G. 1991. Exploration and exploitation in organizational learning. Organization Science, 2 (1): 71-87.

Martin, X. \& Mitchell, W. 1998. The influence of local search and performance heuristics on new design introduction in a new product market. Research Policy 26(7,8): 753-771.

Methe, D., Swaminathan, A., Mitchell, W. \& Toyama, R. 1997. The underemphasized role of diversifying entrants and industry incumbents as the sources of major innovations, In Thomas, H. \& O’Neal, D. (eds). Strategic Discovery: Competing in New Arenas; 99-116, New York: Wiley.

Narin, F., Noma, E. \& Perry, R. 1987. Patents as indicators of corporate technological strength, Research Policy, 16 (2-4): 26-48.

Nelson, R. \& Winter, S. 1982. An Evolutionary Theory of Economic Change. Cambridge, MA: Harvard University Press..

Nohria, N. \& Garcia-Pont C. 1991. Global strategic linkages and industry structure. Strategic Management Journal, 12: 105-124.

Nooteboom, B. 1991. Entry, spending and firm size in a stochastic R\&D race. Small Business Economics, 3: 103-120.

Nooteboom, B.1992. Towards a dynamic theory of transactions. Journal of Evolutionary Economics, 2: 281-99.

Nooteboom, B.1999. Inter-firm alliances: Analysis and design. London: Routledge. 
Nooteboom, B.2000. Learning and innovation in organizations and economies. Oxford:

Oxford University Press.

Nooteboom, B .\& Vossen, R. W. 1995. Firm size and efficiency in R\&D spending. In van

Witteloostuijn, A. (Ed.), Competition and cooperation: 69-86. Deventer, the Netherlands: Kluwer

Pakes, A. \& Griliches, Z. 1984. Estimating distributed lags in short panels with an application to the specification of depreciation patterns and capital Stock constructs. Review of Economic Studies, 51 (2): 243-62.

Penner-Hahn, J. and J. Myles Shaver. 2005. Does international research and development increase patent output? An analysis of Japanese pharmaceutical firms. Strategic Management Journal, 26: 121-140

Penrose, E. T. 1959. The theory of the growth of the firm. Oxford: Basil Blackwell.

Pfeffer, J. \& Nowak, P. 1976. Joint ventures and interorganizational interdependence.

Administrative Science Quarterly, 21: 398-418.

Podolny, J.M. \& Stuart, T.A. 1995. A role-based ecology of technological change, American Journal of Sociology, 100 (5): 1224-1260.

Porter, M. E. 1990. The Competitive Advantage of Nations. London: MacMillan.

Porter, M. E. (Ed.) 1986. Competition in Global Industries. Boston MA: Harvard Business School Press.

Powell, W. W., Koput K.W., \& Smith-Doerr L. 1996. Interorganizational collaboration and the locus of innovation: Networks of learning in biotechnology. Administrative Science Quarterly, 41: 116-145

Prahalad, C.K. \& G. Hamel. 1990. The Core Competence of the Corporation. Harvard Business Review, May-June:79-91. 
Richardson, G. B. 1972. The organization of industry. The Economic Journal, 82(127): 883896.

Ring, P. Smith, \& Van de Ven A.H. 1994. Developmental processes of cooperative interorganizational relationships. Academy of Management Review, 19: 90-118.

Rosenkopf, L. \& Nerkar A. 2001. Beyond Local Search: Boundary-spanning, Exploration, and Impact in the Optical Disc Industry. Strategic Management Journal, 22: 287-306.

Rosenkopf, L. \& Almeida. P. 2003. Overcoming Local Search Through Alliances and Mobility. Management Science, 49:751-766.

Rowley, T. Behrens, D. \& Krackhardt, D. 2000. Redundant governance structures: An analysis of structural and relational embeddedness in the steel and semiconductor industries. Strategic Management Journal, Special Issue, 21 (3): 369-386.

Schein, E. H. 1985. Organizational culture and leadership. San Francisco: Jossey-Bass

Smircich, L. 1983. Organization as shared meaning, in Pondy, L. R., Frost, P. J., Morgan, G. and Dandridge T. C. (Eds.), Organizational symbolism: 55-65. Greenwich Conn: JAI Press.

Stuart, T. \& Podolny J. 1996. Local search and the evolution of technological capabilities. Strategic Management Journal, Summer Special Issue 17: 21-38.

Stuart, T., 1998, Network postions and propensities to collaborate: an investigation of strategic alliance formation in a high-technology industry. Administrative Science Quarterly, 43: 637-668

Tanriverdi, H. and N. Venkatraman, 2005, Knowledge relatedness and the performance of multibusiness firms. Strategic Management Journal, 26: 97-119

Teece, D.J., Pisano, G. \& Shuen, A. 1997. Dynamic capabilities and strategic management. Strategic Management Journal, 18: 509-534. 
Uzzi, B. 1997. Social structure and competition in interfirm networks: The paradox of embeddedness. Administrative Science Quarterly, 42: 35-67.

Weick, K. F. 1979. The social psychology of organizing. Reading, MA: Addison-Wesley.

Weick, K. F 1995. Sensemaking in organizations. Thousand Oaks CA: Sage.

Wernerfelt, B.1984. A resource-based view of the firm. Strategic Management Journal, 5: $171-180$

Wuyts, S., Colombo, M. G., Dutta, S. \& Nooteboom, B. 2005. Empirical tests of optimal cognitive distance. Journal of Economic Behaviour and Organization, forthcoming. 
Figure 1: Optimal cognitive distance

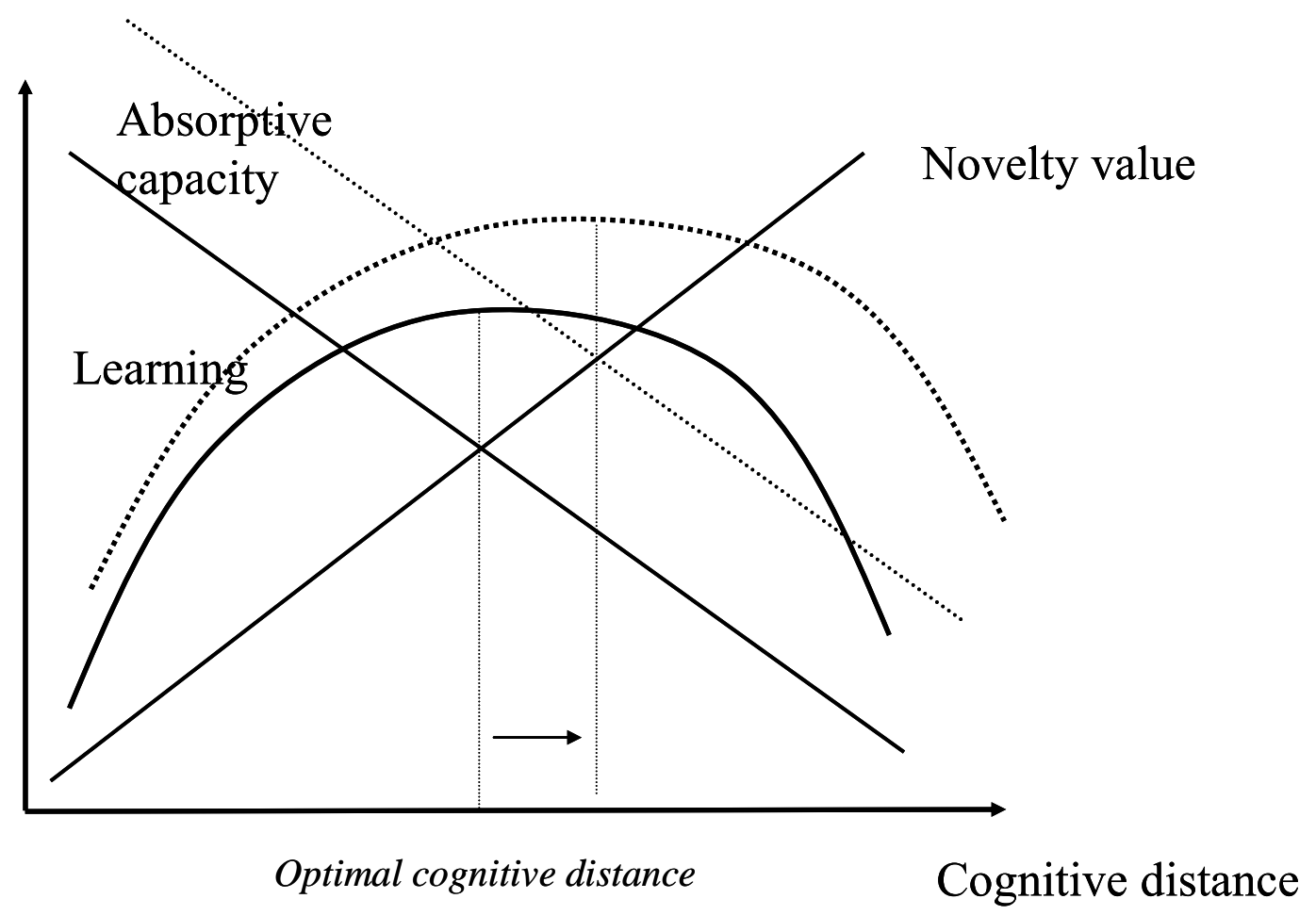

Source: Nooteboom (1999) 


\section{Dependent variables}

Exploitative patents

Explorative patents

\section{Independent variables}

Cognitive distance:

(Cognitive distance $)^{2}$

Cumulative patents
Number of patents a firm successfully filed for in year $t$ within patent classes in which the firm has been active in the five years prior to the given year

Number of patents a firm successfully filed for in year $t$ within patent classes in which is has not been active in the five years prior to the given year. The status of 'explorative patent' is kept for three years.

The average of the correlations between the focal firm's technology profile and that of each of its alliance partners. The variable is transformed; the values range from 0 top 100, where increasing values stand for increasing distances between the technology portfolio of the focal firm and that of its alliance partners. Technology profiles are calculated based on the revealed technology advantage or specialization of each firm in each of the patent classes. Squared term of previous variable

Count of the number patents that a firm successfully filed for during the previous five years ( $t-5$ to $t-1$ ). This variable represents the existing patent portfolio of a firm.

\section{Control variables}

Age

Firm size (ln revenues)

R\&D intensity

Year

Chemical company

Car manufacturer

Europe

US
The number of years since a company is founded

Natural logarithm of the total sales of the firm in $\mathrm{t}-1$ (x 1000 Euro)

$\mathrm{R} \& \mathrm{D}$ expenditures in $\mathrm{t}-1$ divided by total sales in $\mathrm{t}-1$

Dummy variables indicating a particular year in the observed period 1986-1997

Dummy variable set to one if the firm is a chemical company (default = pharmaceutical company)

Dummy variable set to one if the firm is a car manufacturer (default = pharmaceutical company)

Dummy variable set to one if the firm is headquartered in Europe (default $=$ Asian company)

Dummy variable set to one if the firm is headquartered in the U.S. default = Asian company)

Note: All network variables are based on alliance network representing all the technology-based alliances that were established in an industry during the five years prior to year $\mathrm{t}$ 
Table 2: Descriptive statistics and correlation matrix

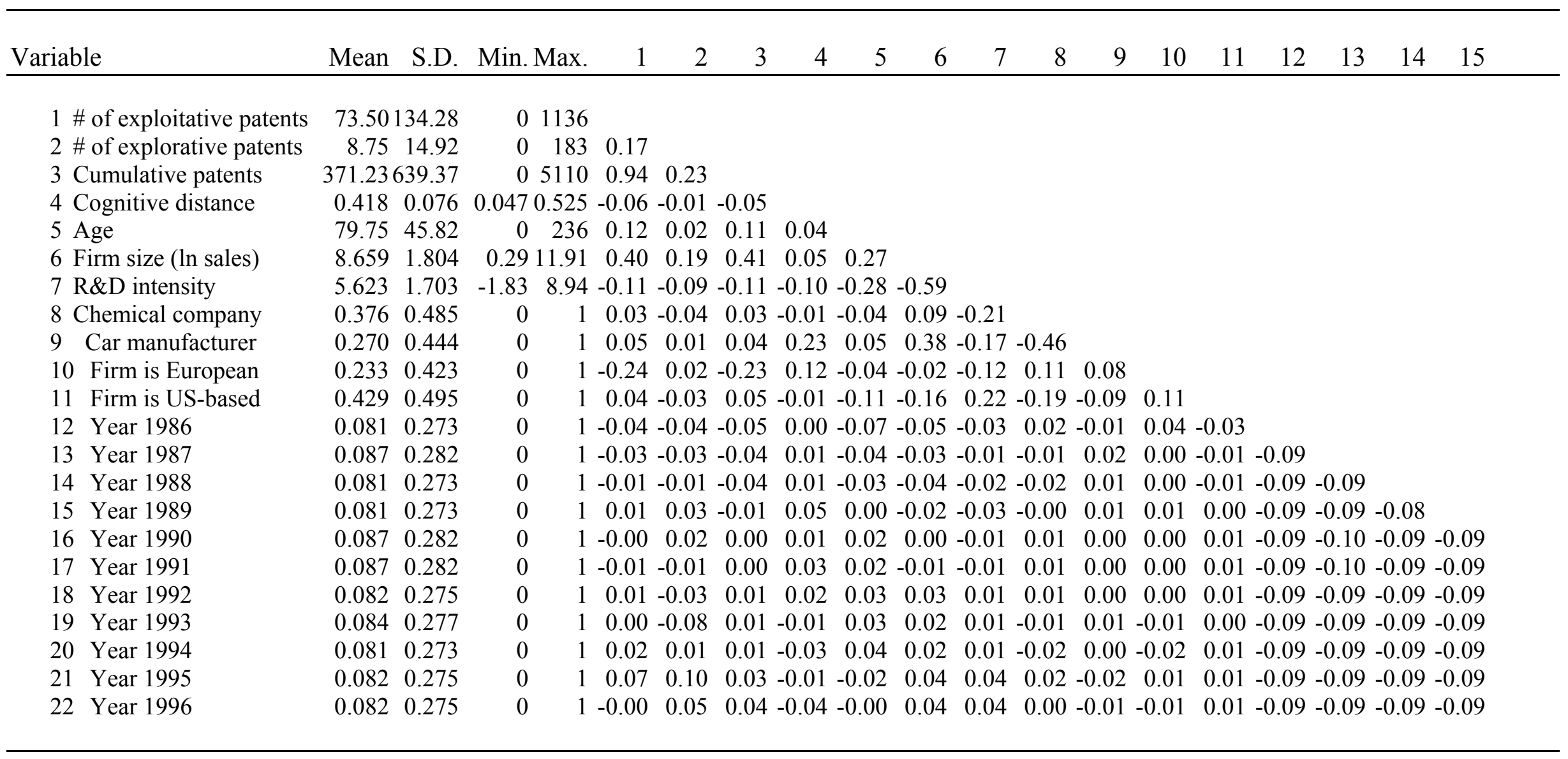


Table 2: Descriptive statistics and correlation matrix (continued)

Variable

$\begin{array}{llllll}16 & 17 & 18 & 19 & 20 & 21\end{array}$

\begin{tabular}{|c|c|c|c|}
\hline 16 Year 1990 & & & \\
\hline 17 Year 1991 & -0.10 & & \\
\hline Year 1992 & -0.09 & -0.09 & \\
\hline Year 1993 & -0.09 & -0.09 & -0.09 \\
\hline 20 Year 1994 & -0.09 & -0.09 & $-0.09-0.09$ \\
\hline 21 Year 1995 & -0.09 & -0.09 & $-0.09-0.09-0.09$ \\
\hline 22 Year 1996 & -0.09 & -0.09 & $\begin{array}{ccc}-0.09 & -0.09-0.09 & -0.09\end{array}$ \\
\hline
\end{tabular}




\begin{tabular}{|c|c|c|c|c|c|c|c|c|}
\hline \multirow[b]{2}{*}{ Variable } & \multicolumn{4}{|c|}{ Exploitative } & \multicolumn{4}{|c|}{ Explorative } \\
\hline & Model 1 & Model 2 & Model 3 & Model 4 & Model 1 & Model 2 & Model 3 & Model4 \\
\hline \multicolumn{9}{|l|}{ Explanatory variables } \\
\hline Cognitive distance ${ }^{\mathrm{C}}$ & & $\begin{array}{l}-1.4420 * * \\
(0.0616)\end{array}$ & $\begin{array}{l}-0.8925 \\
(0.6238)\end{array}$ & $\begin{array}{l}1.5026^{*} \\
(0.8757)\end{array}$ & & $\begin{array}{l}8.5298 * * * \\
(1.9777)\end{array}$ & $\begin{array}{l}8.2221 * * * \\
(1.9801)\end{array}$ & $\begin{array}{l}13.3658 * * * \\
(2.6522)\end{array}$ \\
\hline$(\text { Cognitive distance })^{2}$ & & $\begin{array}{l}0.0059 \\
(0.0082)\end{array}$ & $\begin{array}{l}0.0033 \\
(0.0086)\end{array}$ & $\begin{array}{l}-0.02857^{* *} \\
(3.6911)\end{array}$ & & $\begin{array}{l}-0.1119 * * * \\
(0.0026)\end{array}$ & $\begin{array}{l}-0.09828 * * * \\
(0.02631)\end{array}$ & $\begin{array}{l}-1.6445^{* * * *} \\
(0.0347)\end{array}$ \\
\hline Cumulative patents /1000 & & & $\begin{array}{l}0.2277 * * * \\
(0.0466)\end{array}$ & $\begin{array}{l}0.9205 * * * \\
(0.1778)\end{array}$ & & & $\begin{array}{l}0.8005 * * * \\
(0.2075)\end{array}$ & $\begin{array}{l}3.4117 * * * \\
(0.8516)\end{array}$ \\
\hline \multicolumn{2}{|l|}{ ((Cognitive distance) } & & $-0.2539 * *$ & $-3.9053 * * *$ & & & $-1.4815 * * *$ & $-14.9983 * * *$ \\
\hline \multirow{2}{*}{\multicolumn{2}{|c|}{$\begin{array}{l}*(\text { cumulative patents })) / 1000 \\
\left((\text { Conitive distance })^{2}\right.\end{array}$}} & & $(0.1112)$ & $(0.0 .9095)$ & & & $(0.4830)$ & $(4.3157)$ \\
\hline & & & & $0.0473 * * *$ & & & & $0.1725 * * *$ \\
\hline \multicolumn{2}{|l|}{$*($ cumulative patents $)) / 1000$} & & & $(0.0117)$ & & & & $(0.0549)$ \\
\hline \multicolumn{9}{|l|}{ Control variables $^{\mathrm{A}}$} \\
\hline Firm size (ln sales) & $\begin{array}{l}0.6944 * * * \\
(0.0221)\end{array}$ & $\begin{array}{l}0.8141 * * * \\
(0.0241)\end{array}$ & $\begin{array}{l}0.7659 * * * \\
(0.0243)\end{array}$ & $\begin{array}{l}0.7567 * * * \\
(0.0243)\end{array}$ & $\begin{array}{l}0.3473 * * * \\
(0.0385)\end{array}$ & $\begin{array}{l}0.4269 * * * \\
(0.0460)\end{array}$ & $\begin{array}{l}0.4074 * * * \\
(0.0465)\end{array}$ & $\begin{array}{l}0.4016 * * * \\
(0.4639)\end{array}$ \\
\hline R\&D-intensity & $\begin{array}{l}0.2171 * * * \\
(0.0224)\end{array}$ & $\begin{array}{l}3.0286 * * * \\
(0.2127)\end{array}$ & $\begin{array}{l}2.6096 * * * \\
(0.2111)\end{array}$ & $\begin{array}{l}2.5926 * * * \\
(0.2109)\end{array}$ & $\begin{array}{l}0.1418 * * * \\
(0.0264)\end{array}$ & $\begin{array}{l}1.1325 * * * \\
(0.2452)\end{array}$ & $\begin{array}{l}1.0844 * * * \\
(0.2461)\end{array}$ & $\begin{array}{l}1.0779 * * * \\
(0.2454)\end{array}$ \\
\hline Age & $\begin{array}{l}0.0091 * * \\
(0.0034)\end{array}$ & $\begin{array}{l}0.0132 * * * \\
(0.0042)\end{array}$ & $\begin{array}{l}0.0122 * * * \\
(0.0040)\end{array}$ & $\begin{array}{l}0.0120 * * * \\
(0.0040)\end{array}$ & $\begin{array}{l}-0.0024 \\
(0.0022)\end{array}$ & $\begin{array}{l}-0.0015 \\
(0.0025)\end{array}$ & $\begin{array}{l}-0.0016 \\
(0.0025)\end{array}$ & $\begin{array}{l}-0.0017 \\
(0.0025)\end{array}$ \\
\hline Car manufacturer & $\begin{array}{l}-1.2739 * * * \\
(0.3980)\end{array}$ & $\begin{array}{l}-0.8887 * * \\
(0.4303)\end{array}$ & $\begin{array}{l}-0.8787 * * \\
(0.4138)\end{array}$ & $\begin{array}{l}-0.8643 * * \\
(0.4109)\end{array}$ & $\begin{array}{l}-1.0037^{* * *} \\
(0.2715)\end{array}$ & $\begin{array}{l}-0.8841 * * * \\
(2980)\end{array}$ & $\begin{array}{l}-0.8951 * * * \\
(0.2957)\end{array}$ & $\begin{array}{l}-0.8919 * * * \\
(0.2934)\end{array}$ \\
\hline Chemical industry & $\begin{array}{l}-0.6093 \\
(0.3763)\end{array}$ & $\begin{array}{l}-0.2628 \\
(0.4047)\end{array}$ & $\begin{array}{l}-0.2529 \\
(0.3908)\end{array}$ & $\begin{array}{l}-0.2502 \\
(0.3879)\end{array}$ & $\begin{array}{l}-0.6218 * * \\
(0.2545)\end{array}$ & $\begin{array}{l}-0.5570 * * \\
(0.2698)\end{array}$ & $\begin{array}{l}-0.5427^{* *} \\
(0.2700)\end{array}$ & $\begin{array}{l}-0.5438 * * \\
(0.2678)\end{array}$ \\
\hline Europe & $\begin{array}{l}0.0975 \\
(0.4293)\end{array}$ & $\begin{array}{l}0.4870 \\
(0.4834)\end{array}$ & $\begin{array}{l}0.4114 \\
(0.4598)\end{array}$ & $\begin{array}{l}0.3856 \\
(0.4551)\end{array}$ & $\begin{array}{l}0.2995 \\
(0.2734)\end{array}$ & $\begin{array}{l}0.3651 \\
(0.2988)\end{array}$ & $\begin{array}{l}0.3712 \\
(0.2956)\end{array}$ & $\begin{array}{l}0.3714 \\
(0.2930)\end{array}$ \\
\hline US & $\begin{array}{l}0.2976 \\
(0.3635)\end{array}$ & $\begin{array}{l}0.1526 \\
(0.3781)\end{array}$ & $\begin{array}{l}0.1809 \\
(0.3678)\end{array}$ & $\begin{array}{l}0.1829 \\
(0.3660)\end{array}$ & $\begin{array}{l}0.1462 \\
(0.2468)\end{array}$ & $\begin{array}{l}-0.0185 \\
(0.2652)\end{array}$ & $\begin{array}{l}-0.0067 \\
(0.2646)\end{array}$ & $\begin{array}{l}0.0044 \\
(0.2628)\end{array}$ \\
\hline Constant & $\begin{array}{l}-2.3043^{* * *} \\
(0.4810)\end{array}$ & $\begin{array}{l}-3.5984 * * * \\
(0.5590)\end{array}$ & $\begin{array}{l}-3.4006^{* * *} \\
(0.5489)\end{array}$ & $\begin{array}{l}-3.7412 * * * \\
(0.5533)\end{array}$ & $\begin{array}{l}-0.5362 \\
(0.4220)\end{array}$ & $\begin{array}{l}-2.9135 * * * \\
(0.6452)\end{array}$ & $\begin{array}{l}-2.9734 * * * \\
(0.6490)\end{array}$ & $\begin{array}{l}-3.9018 * * * \\
(0.7242)\end{array}$ \\
\hline
\end{tabular}


Number of firms

$(0.2632)$

(0.1310)

(0.1445)

(0.1437)

(0.1419)

Number of firms-years

$\begin{array}{lll}93 & 85 & 85 \\ 922 & 762 & 762 \\ -6140.8 & -5402.2 & -5337.0\end{array}$

85

Log-Likelihood

$-6140.8$

$-5337.0$

93

922

\section{5}

762

762

85

$-5328.9 \quad-3578.6$

$-2999.5$

$-2987.5$

$-2982.7$

Notes: Standard error between brackets

$* * * \quad p<0.01 ; * * p<0.05 ; * p<0.10$

A: 'Year dummy variable'-coefficients are included in the regressions but are not reported in the table.

B: Likelihood-ratio test of alpha $=0$

$\mathrm{C}$ : 'Cognitive distance' has been divided by 100 in the respective explanatory variables and interaction terms in order to have readable coefficients. 
Figure 1:

Optimal cognitive distance for “exploitative patents" based on model 4 in Table 3

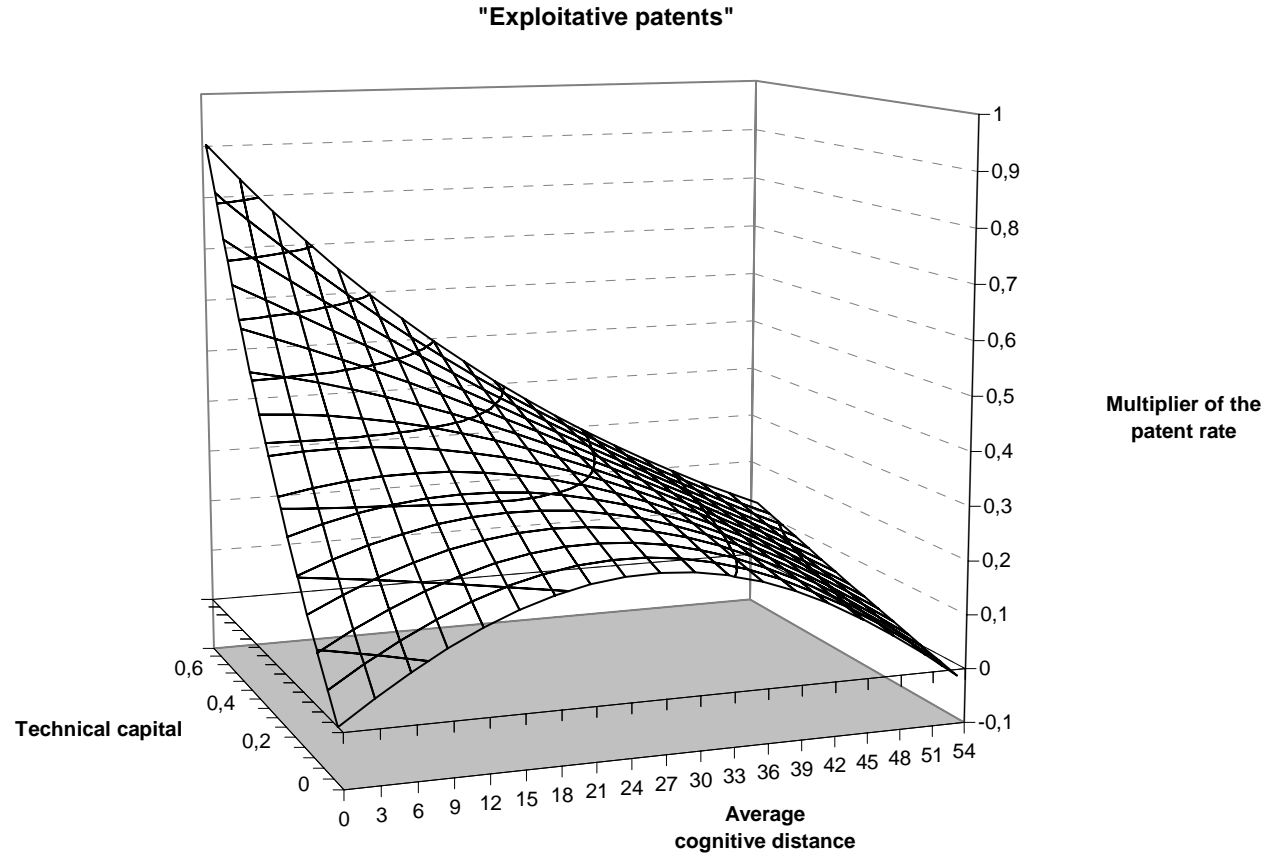

Figure 2:

Optimal cognitive distance for "exploitative patents" based on model 4 in Table 3 but the axes are resized in the same way as in Figure 3

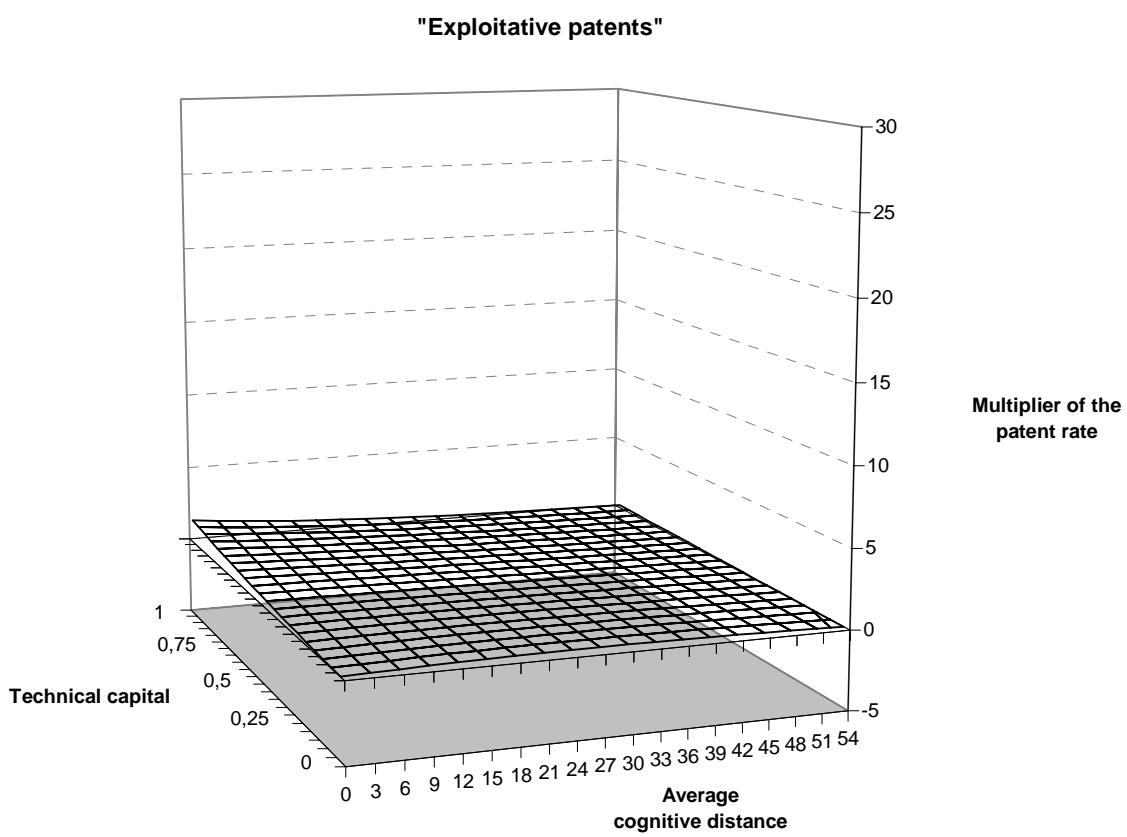


Figure 3:

Optimal cognitive distance for “explorative patents" based on model 4 in Table 3

"Explorative patents"

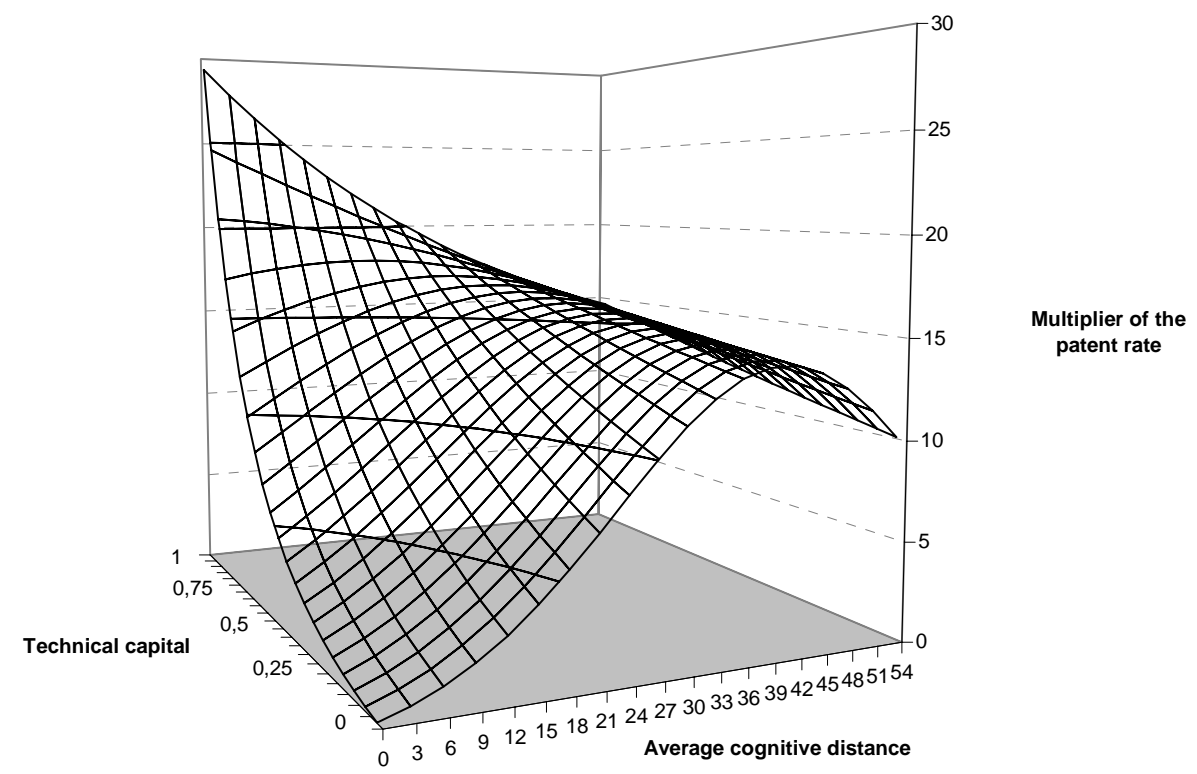




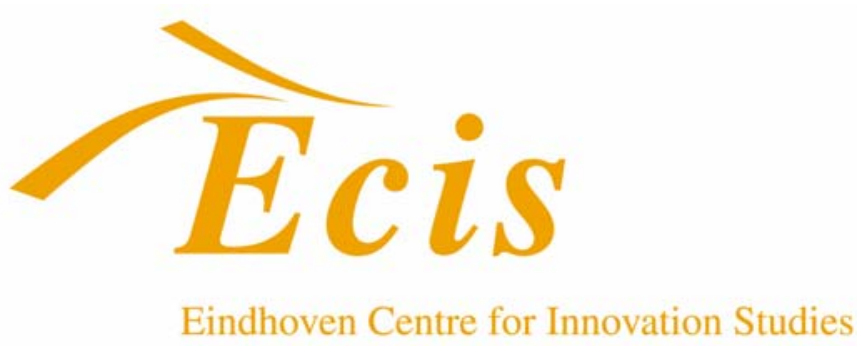

W O R K I N G P A P R S

Ecis working papers 2004/ 2005:

$04.01 \quad$ B. Nooteboom \& V.A. Gilsing

Density and strength of ties in innovation networks: a competence and governance view

04.02 A. Nuvolari

Collective invention during the British Industrial Revolution: the case of the Cornish pumping engine

04.03 C. Meister \& B. Verspagen

European Productivity Gaps: Is R\&D the solution?

04.04 J.J. Berends, J.D. van der Bij, K. Debackere, M.C.D.P. Weggeman

Knowledge sharing mechanisms in industrial research

04.05 J.J. Berends, K. Debackere, R. Garud, M.C.D.P. Weggeman

Knowledge integration by thinking along

04.06 M.H.C. Ho

Differences between European Regional Innovation Systems in terms of technological and economic caracteristics

04.07 F.E.A. van Echtelt, J.Y.F. Wynstra, A.J. van Weele van,., Duysters, G.M Critical processes for managing supplier involvement in new product development: an in-depth multiplecase study

04.08 H.A. Akkermans, I.S. Lammers, M.C.D.P. Weggeman All ye need to know? Aesthetics from a design perspective

04.09 V. Gilsing \& B. Nooteboom

Co-evolution in innovation systems: the case of pharmaceutical biotechnology

04.10 J.E. van Aken

Co-evolution in innovation systems: the case of pharmaceutical biotechnology

04.11 J.E. van Aken

Valid knowledge for the professional design of large and complex design processes

04.12 J.E. van Aken

Organising and managing the fuzzy front end of new product development

04.13 C. Werker \& T. Brenner

Empirical calibration of simulation models

04.14 J. Jacob \& C. Meister

Productivity gains, intersectoral linkages, and trade: Indonesian manufacturing, 1980-1996 
04.15 B. Verspagen

Innovation and Jobs: a Micro-and-Macro Perspective

04.16 V. Gilsing \& B. Nooteboom

Density and strength of ties in innovation networks: an analysis of multimedia and biotechnology

04.17 G. Silverberg \& B. Verspagen

The size distribution of innovations revisited: an application of extreme value statistics to citation and value measures of patent significance

04.18 J. Jacob

Late industrialisation and structural change: the Indonesian experience

04.19 C. Garavaglia

"History Friendly" Simulations for Modelling Industrial Dynamics

04.20 K.H. Heimeriks, G.M. Duysters, W.P.M. Vanhaverbeke

The evolution of alliance capabilities

$04.21 \quad$ K.H. Heimeriks \& G.M. Duysters

A study into the alliance capability development process

05.01 V.A. Gilsing \& B. Nooteboom

In search of the origins of novelty: exploring novel combinations in allopatric speciation

05.02 V.A. Gilsing \& C.E.A.V. Lemmens

Strategic alliance networks and innovation: a deterministic and voluntaristic view combined

05.03 M.C.J. Caniëls \& H.A. Romijn

What Works, and Why, in Business Services Provision for SMEs: Insights from evolutionary theory

05.04 C. Macleod \& A. Nuvolari

'The Ingenious Crowd': A Critical Prosopography of British Inventors, 1650-1850

05.05 B. Nooteboom, W.P.M. Vanhaverbeke, G.M. Duysters, V.A. Gilsing, A.J. van den Oord Optimal cognitive distance and absorptive capacity 